\title{
GENOTYPIC CHARACTERIZATION OF MICROSATELLITE MARKERS IN BROILER AND LAYER SELECTED CHICKEN LINES AND THEIR RECIPROCAL $\mathrm{F}_{1} \mathrm{~s}$
}

\author{
Millor Fernandes do Rosário ${ }^{1}$; Mônica Corrêa Ledur²; Ana Silvia Alves Meira Tavares Moura ${ }^{3}$; \\ Luiz Lehmann Coutinho ${ }^{4 *}$; Antonio Augusto Franco Garcia ${ }^{5}$ \\ ${ }^{1}$ USP/ESALQ - Programa de Pós-Graduação em Genética e Melhoramento de Plantas. \\ ${ }^{2}$ Embrapa Suínos e Aves, C.P. 21 - 89700-000 - Concórdia, SC - Brasil. \\ ${ }^{3}$ UNESP/FMVZ - Depto. de Produção Animal, C.P. 560 - 18618-000 - Botucatu, SP - Brasil. \\ ${ }_{5}^{4}$ USP/ESALQ - Depto. de Zootecnia, C.P. 9 - 13418-900 - Piracicaba, SP - Brasil. \\ ${ }^{5}$ USP/ESALQ - Depto. de Genética, C.P. 83 - 13400-970 - Piracicaba, SP - Brasil. \\ *Corresponding author <llcoutin@esalq.usp.br>
}

ABSTRACT: Chicken experimental populations have been developed worldwide for QTL mapping, but their genotypic characterizations are not usually discussed. The objective of this study was to characterize genotypically two $\mathrm{F}_{1}$ reciprocal generations and their parental lines based on the estimation of genotypic parameters. These $\mathrm{F}_{1}$ generations originated two Brazilian reference populations to map QTL. The evaluated parameters were polymorphic information content (PIC), observed and expected heterozygosities and number of alleles at microsatellite loci on chromosomes 1, 3 and 4. All parental and $F_{1}$ chickens from both populations were used totalling of 83 chickens: 14 from a broiler (TT) and 14 from a layer line $(\mathrm{CC})$ and 55 from their reciprocal $\mathrm{F}_{1}$ generations. The chicken lines and the resource populations were developed at the National Research Center for Swine and Poultry (EMBRAPA), Brazil. Genotypes from all animals were obtained from 34 loci on chromosomes 1 (13), 3 (12) and 4 (9). Based on the sampling, we found that the two lines exhibited a total of 163 different alleles, of which $31(31.1 \%)$ and $44(33.0 \%)$ alleles were unique in $\mathrm{CC}$ and TT lines, respectively, with allelic frequencies ranging from 0.03 to 0.82 . The observed heterozygosity was higher $(0.68-0.71)$ in both $F_{1}$ generations than in their founder lines due to linkage disequilibrium. Finally, the two chicken lines used as founders created two $\mathrm{F}_{1}$ reciprocal generations with high levels of PIC (0.50-0.52) and observed heterozygosity, as well as satisfactory number of alleles per locus (4.06-4.32). Our results will allow to compare and select families with highly informative microsatellite markers for QTL studies, reducing genotyping costs.

Key words: PIC, genotypic diversity, heterozygosity, number of alleles

\section{CARACTERIZAÇÃO GENOTÍPICA DE LINHAGENS SELECIONADAS DE GALINHA DE CORTE E POSTURA E SEUS F $s$ RECÍPROCOS USANDO MARCADORES MICROSSATÉLITES}

\begin{abstract}
RESUMO: Populações experimentais de frangos tem sido desenvolvidas pelo mundo para mapeamento de QTLs, mas a caracterização genotípica delas não é normalmente apresentada. O objetivo deste estudo foi caracterizar genotipicamente duas gerações $F_{1}$ recíprocas e suas linhagens parentais com base na estimação de parâmetros genotípicos. Estas gerações $F_{1}$ originaram duas populações brasileiras referências para mapear QTLs. Os parâmetros avaliados foram: conteúdo de informação polimórfica $(P I C)$, heterozigosidades observada e esperada e número de alelos por loco nos cromossomos 1,3 e 4 . Todos os animais parentais e $F_{1}$ de ambas as populações foram usados, em um total de 83 animais: 14 de uma linhagem de corte (TT) e 14 de uma linhagem de postura (CC), e 55 de suas gerações recíprocas $F_{1}$. Tanto as linhagens como as populações referências foram desenvolvidas no Centro Nacional de Pesquisa de Suínos e Aves (EMBRAPA), Brasil. Os genótipos de todos os animais foram obtidos a partir de 34 marcadores microssatélites localizados nos cromossomos 1 (13), 3 (12) e 4 (9). Com base na amostragem realizada, as duas linhagens exibiram um total de 163 alelos, dos quais $31(31,1 \%)$ e $44(33,0 \%)$ foram oriundos exclusivamente de CC e TT, respectivamente, com freqüências alélicas que variaram de 0,03 a 0,82 . A heterozigosidade observada foi maior $(0,68-$ $0,71)$ em ambas as gerações $F_{1}$ do que em suas linhagens fundadoras devido ao desequilíbrio de ligação. Finalmente, as duas linhagens parentais possibilitaram a obtenção de gerações recíprocas
\end{abstract}


$\mathrm{F}_{1}$ com valores elevados de PIC $(0,50-0,52)$ e heterozigosidade observada, bem como com um número satisfatório de alelos por loco $(4,06-4,32)$. Estes resultados permitirão comparar e selecionar famílias e marcadores microssatélites mais informativos em estudos de QTLs, reduzindo os custos de genotipagem.

Palavras-chave: PIC, diversidade genotípica, heterozigosidade, número de alelos

\section{INTRODUCTION}

In Brazil, two $\mathrm{F}_{2}$ chicken populations for mapping QTL for performance and carcass traits were developed in 1999 with joint efforts of the National Research Center for Swine and Poultry, from EMBRAPA, in association with the "Luiz de Queiroz" College of Agriculture of the University of São Paulo. These populations were named TCTC and CTCT because they were developed from the reciprocal crossbreeding of a broiler line (TT) and a layer line (CC). Phenotypic description of these populations is in Zanella et al. (2000) and Ledur \& Bertani (2002). Description of other experimental chicken populations can be found in a review about QTL published by Abasht et al. (2006).

Nevertheless these two chicken populations have not been described genotypically yet. Using microsatellite markers and estimating genotypic parameters such as polymorphism information content (PIC) and heterozygosity are recommended strategies for determining the informativeness of markers. From these two parameters, there are two strategies to increase the power for QTL detection and reduce the genotyping costs in chicken populations: the first one is a forward strategy, where prior to create the experimental population, an initial screening of chickens from parental lines can be useful to select the highly informative parental that present the best combination of these parameters, generating $\mathrm{F}_{1}$ families with increased genotypic polymorphic content; and the second is the reverse strategy, where after the experimental population is created, a screening of all $\mathrm{F}_{1}$ families can be useful to select highly informative families (Hillel, 1997; Zhu et al., 2001).

It is also possible that these genotypic parameters are used in other QTL studies because they provide information about markers in populations designed to map QTL and this information has not been published yet. Although genotypic description can vary among populations due to different genetic background, this information can help the initial selection of more informative markers and families in QTL studies. Therefore, the purpose of this study was to report the genotypic parameters for two $\mathrm{F}_{1}$ generations used to create two $\mathrm{F}_{2}$ resource populations to map QTL and their parental lines, using microsatellite loci from chromosomes 1, 3 and 4.

\section{MATERIAL AND METHODS}

\section{Chicken lines and their $F_{1}$ generations}

TT is a male broiler line whose selection program involved within line selection for six generations to improve body weight, feed conversion, carcass and breast yields, viability, fertility, eclodibility, reduction of abdominal fat and metabolic syndromes (ascites and sudden death). CC is a layer line whose selection program involved within line selection for eight generations to improve egg production, egg weight, feed conversion, viability, sexual maturity, fertility, eclodibility, egg quality and reduction of body weight.

The lines also differ in their genetic background. The broiler line TT originated from White Plymouth Rock, New Hampshire and White Cornish breeds, while the layer line $\mathrm{CC}$ was originated from the White Leghorn breed. Both lines were developed at the National Research Center for Swine and Poultry - EMBRAPA, Brazil. Details on the EMBRAPA Poultry Breeding Program are in Figueiredo et al. (2003a, 2003b).

Two $\mathrm{F}_{2}$ chicken resource populations (TCTC and CTCT) were developed at EMBRAPA by reciprocally crossing the broiler line (TT) and the layer line (CC). This aimed at producing populations with segregating QTL for performance and carcass traits. Seven TT males were mated to seven CC females to generate about $50 \mathrm{~F}_{1}$ TC chickens, and seven $\mathrm{CC}$ males were mated to seven TT females to generate about 50 $\mathrm{F}_{1} \mathrm{CT}$ chickens. A total of seven males and 21 females (one male and three females from each full-sib family) from the $F_{1}$ generation were selected to be parents of the $F_{2}$ population. Each $F_{1}$ male was mated to three non-related $F_{1}$ females to produce the $F_{2}$ generation. Each female produced around $100 \mathrm{~F}_{2}$ offspring (Zanella et al., 2000). Figure 1 shows a scheme of the design of these populations.

In the present study, data from the parental TT (14) and CC (14) chicken lines and their $\mathrm{F}_{1}$ generations (28 TC and $27 \mathrm{CT}$ ) were used. One $\mathrm{F}_{1} \mathrm{CT}$ female died before its blood sample was collected.

\section{Analysis of DNA, genotypes and pedigree}

Genomic DNA from parental and $\mathrm{F}_{1}$ generations of TCTC and CTCT populations was extracted from blood samples using the DNAzol ${ }^{\circledR}$ reagent (Invitrogen Life Technologies). Thirty-four 


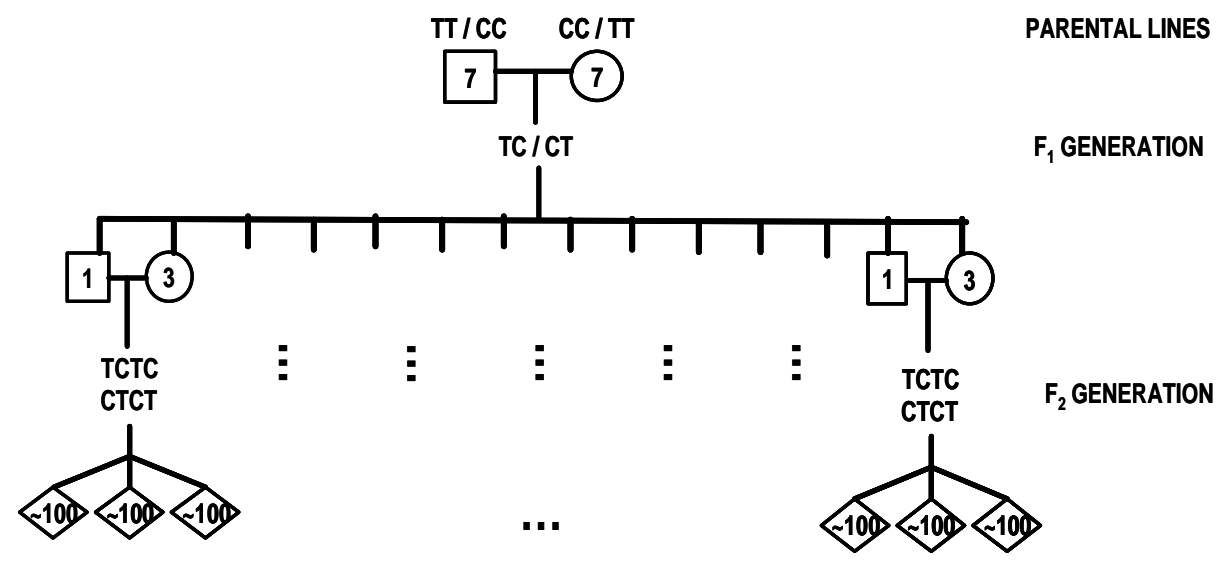

Figure 1 - Simplified scheme of the design of two Brazilian $\mathrm{F}_{2}$ chicken resource populations to map QTL for performance and carcass traits generated from crosses between a layer (CC) and a broiler (TT) lines. The symbols $\square, \bigcirc$ and $\diamond$ represent male, female and mixed sex, respectively.

microsatellite markers covering chromosomes 1 (13 ADL0234, MCW0297, LEI0174, ADL0150, MCW0112, MCW0058, LEI0071, LEIO160, LEI0169, LEI0079, LEI0107, ADL0183, MCW0145), 3 (12 LEI0043, MCW0169, MCW0083, ADL0370, MCW0222, LEI0161, LEI0115, ADL0371, LEI0118, $M C W 0277, A D L 0127, M C W 0116)$ and 4 (9 LEI0100, ADL0194, LEI0122, LEI0062, LEI0076, MCW0240, LEI0063, LEI0085, MCW0174) were used. The primer sequences (forward and reverse) are available at $<\mathrm{http}: / / \mathrm{www}$.thearkdb.org/>. These markers covered a total of $665 \mathrm{cM}$, about $16 \%$ of the chicken genome according to Consensus Linkage Map (Schmid et al., 2005).

Each PCR reaction had total volume of $15 \mu \mathrm{L}$ containing $4.00 \eta \mathrm{g} \mu \mathrm{L}^{-1}$ of DNA, forward and reverse primers ranging from 0.10 to 0.47 pmol $\mu \mathrm{L}^{-1}, \mathrm{MgCl}_{2}$ ranging from 2.00 to $7.00 \mathrm{mM}$, buffer with $50 \mathrm{mM}$ $\mathrm{KCl}$ and $10 \mathrm{mM}$ Tris-HCl pH 8.5, $0.40 \mathrm{mM}$ of dNTP and Taq DNA polymerase ranging from 0.07 to 0.40 $\mathrm{U} \mu \mathrm{L}^{-1}$. The genomic DNA was amplified in thermocycler according to the following program: initial denaturation at $94^{\circ} \mathrm{C}$ for 2 minutes, and 30 cycles of: 1 minute at $94^{\circ} \mathrm{C}, 1$ minute at 47 to $66^{\circ} \mathrm{C}$ (annealing temperature) depending on primer sequence, and an extension of 1 minute at $72^{\circ} \mathrm{C}$. After the 30 cycles, an extension at $72^{\circ} \mathrm{C}$ for 10 minutes was conducted.

PCR products from up to four markers were mixed for allele size and fluorescence determinations in a MegaBACE ${ }^{\circledR}$ genotyper (GE Healthcare). Fragment size (alleles) was determined employing the Genetic Profiler $^{\circledR}$ software (GE Healthcare) using ETROX- $400^{\circledR}$ (GE Healthcare) as an internal molecular weight pattern.

Genotypes from parental chickens (TT and $\mathrm{CC})$ were used to check the pedigree within population using the PEDCHECK software ${ }^{\circledR}$ at $<$ http:// bioinfo.cs.technion.ac.il/superlink-online/makeped/ pedcheck.shtml> (Fishelson \& Geiger, 2002).

\section{Estimation of genotypic parameters}

Allelic frequencies and goodness-of-fit tests for Hardy-Weinberg expected proportions using Markov chain method $(p<0.05)$ for each locus with multiple alleles (Guo \& Thompson, 1992) were obtained with the Genepop software ${ }^{\circledR}$ (Raymond \& Rousset, 1995). The Markov chain parameters were: number of dememorization (1000), number of batches (100) and number of iterations per batch (1000).

Polymorphism information content $(P I C)$ was calculated using the formula:

$$
P I C=1-\sum_{i=1}^{j} P_{i}^{2}-2 \sum_{i=j+1}^{j} \sum_{j=1}^{i-1} P_{i}^{2} P_{j}^{2}
$$

where $P_{i}$ and $P_{j}$ are the frequencies of the $i^{\text {th }}$ and $j^{\text {th }}$ alleles at a locus with $l$ alleles in a population, respectively (Botstein et al., 1980).

Observed heterozygosity ( $\mathrm{Het}_{\text {obs }}$ ) was calculated based on the actual counts of heterozygous markers in an individual chicken using:

Het $_{\text {obs }}=\left(\sum_{i=1}^{N} Z_{j}\right) / N$

where $Z_{j}$ is the actual count of heterozygous chickens at locus $j$, and $N$ is the total number of chickens. Unbiased Nei's expected heterozygosity $\left(\mathrm{Het}_{\mathrm{exp}}\right)$ assuming Hardy-Weinberg expected proportions was obtained using the formula:

$H e t_{\exp }=\frac{2 N}{2 N-1}\left(1-\sum_{j=1}^{l} P_{j}^{2}\right)$

where $P_{j}$ is the frequency for the $j^{\text {th }}$ allele at the $i^{\text {th }}$ locus with $l$ alleles in a population, and $N$ is the number of chickens (Nei, 1987). 
PIC and heterozygosities were estimated for each locus using the Cervus ${ }^{\circledR}$ software (Marshall et al., 1998; Slate et al., 2000; Kalinowski et al., 2007) in Allele Frequency Analysis mode with Bonferroni correction for multiple tests. We presented results from PIC and heterozygosities based on arithmetic average across all loci.

\section{RESULTS AND DISCUSSION}

This is the first report of the genotypic characterization of two Brazilian chicken lines and their $F_{1}$ reciprocal generations that were used to create two $F_{2}$ resource populations. These populations have been used for QTL mapping for performance and carcass traits (Nones et al., 2005; Ruy et al., 2005; Nones et al., 2006; Ambo et al., 2008).

We estimated genotypic parameters for $\mathrm{F}_{1}$ generations, and their parental chicken lines based on microsatellite loci from chromosomes 1, 3 and 4. Genotypic diversity across all estimated parameters was observed in both generations. In a preliminary study, Rosário et al. (2006) found that $\mathrm{F}_{1} \mathrm{TC}$ had a slightly higher overall genotypic diversity than $\mathrm{F}_{1} \mathrm{CT}$ when those authors used only 22 microsatellite markers and no standard errors were estimated on genotypic parameters (PIC and heterozygosities). In this study we used the information from those 22 plus 12 new microsatellite markers and we estimated the standard errors of each genotypic parameter. Thus, we found that both $\mathrm{F}_{1}$ generations were similar, which is acceptable since both were created from the same founder lines, differing only in the reciprocal crosses. Other studies have been carried out to assess genetic diversity in chickens using microsatellite markers (Vanhala et al., 1998; Kaiser et al., 2000; Romanov \& Weigend, 2001; Hillel et al., 2003). In general, these studies established the Red Jungle Fowl as the main progenitor of the domesticated chickens.

Some measures of marker information, such as PIC and heterozygosity, increase as a function of the number of alleles per locus considering the same allelic frequency (Lynch \& Walsh, 1998). For example, increasing from 2 up to 8 alleles per locus, PIC increased from 0.40 to 0.80 and heterozygosity from 0.45 to 0.80 . According to Figures 2, 3 and 4, the 34 microsatellite markers on chromosomes 1, 3 and 4 exhibited a total 163 different alleles in both lines. In the CC line 106 alleles (mean of $3.12 \pm 0.19$ per locus) were found, whereas in the TT line 133 alleles (mean of $3.92 \pm 0.26$ per locus) were detected. The number of alleles per locus ranged from 1 (MCW0277) to 7 (LEI0076) for the CC line and from 2 (LEI0062, MCW0058, LEI0043, MCW0083 and
$M C W 0116$ ) to 7 (LEI0107, MCW0169 and $M C W 0240)$ for the TT line. Allelic frequencies ranged from 0.03 to 0.93 for both lines. Results showed that $4(11.7 \%)$ and $6(17.6 \%)$ markers did not fit Hardy-Weinberg expected proportions for CC and TT lines, respectively. These deviations may be caused by the small sample size (14 parental chickens in each line) and/or the close linkage between the markers used and some loci selected in the lines. From 163 different alleles, a total of $31(31.1 \%)$ and $44(33.0 \%)$ alleles were unique in $\mathrm{CC}$ and $\mathrm{TT}$ lines, respectively, and their allelic frequencies ranged from 0.03 to 0.82 .

To reduce confounding of allele sizes due to genotyping errors, we considered an interval of \pm 2 base pairs as a criterion to compare our results with those of the Animal Sciences Group at AceBrowser of Wageningen University and Research Center at $<$ https:/ /acedb.asg.wur.nl $>$ which contains data from the populations reported by Groenen et al. (2000) to map QTL. According to this criterion, we found 15.2 (CC) and 44.6 (TT) \% higher average number of alleles per locus than that database for the same loci. This result was surprising because we expected that the number of alleles per locus in our lines would be lower than the database, which was composed only by genotypes from backcross or $F_{2}$ populations (with no genotypes from their founder lines). The microsatellite markers used here are the same as those used in the database, but they were developed in the populations reported by Groenen et al. (2000), which present similar, but not the same genetic background: Red Jungle Fowl, White Leghorn and White Plymouth Rock as in our study. Therefore, one possible explanation for divergence between our results and the database may be the genetic background. In addition, the lines used to develop the populations reported by Groenen et al. (2000) were selected for different purposes, with some being inbred lines which would lead to fixing some alleles and losing others.

Although current chickens that are used commercially for both meat and egg production are domesticated fowl and descendants from the Red Jungle Fowl species (Al-Nasser et al., 2007), differences among allelic frequencies have been found as result of poultry breeding programs (Vanhala et al., 1998). In our TT line, the New Hampshire and White Cornish breeds are also part of its genetic background, which may also be an explanation for the discrepancies in number of alleles per locus between our lines and that of the Animal Sciences Group database. This extra percentage of total alleles in our founder lines probably gives us support to map new QTL for performance and carcass traits in our populations. 
PIC values, observed and expected heterozygosities for each locus are presented in Table 1. These data are important for marker selection, since they allow the use of both markers and families which are more informative for QTL mapping. The average PIC

Table 1 - Polymorphism information content (PIC), observed $\left(\mathrm{Het}_{\text {obs }}\right)$ and expected ( $\left.\mathrm{Het}_{\mathrm{exp}}\right)$ heterozygosities for each locus microsatellite marker.

\begin{tabular}{|c|c|c|c|c|c|c|}
\hline \multirow{2}{*}{ Marker } & \multicolumn{2}{|c|}{$P I C$} & \multicolumn{2}{|c|}{$\mathrm{Het}_{o b s}$} & \multicolumn{2}{|c|}{$\mathrm{Het}_{\text {exp }} *$} \\
\hline & $\mathrm{CC}$ & TT & $\mathrm{CC}$ & TT & $\mathrm{CC}$ & TT \\
\hline \multicolumn{7}{|c|}{ Chromosome 1} \\
\hline$A D L 0234$ & 0.46 & 0.23 & 0.50 & 0.57 & 0.29 & 0.26 \\
\hline$M C W 0297$ & 0.13 & 0.41 & 0.14 & 0.14 & 0.43 & 0.49 \\
\hline LEIO174 & 0.42 & 0.49 & 0.50 & 0.55 & 0.64 & 0.57 \\
\hline$A D L 0150$ & 0.37 & 0.30 & 0.50 & 0.42 & 0.36 & 0.32 \\
\hline$M C W 0112$ & 0.37 & 0.35 & 0.50 & 0.42 & 0.43 & 0.38 \\
\hline$M C W 0058$ & 0.43 & 0.35 & 0.50 & 0.50 & 0.14 & 0.48 \\
\hline LEI0071 & 0.43 & 0.66 & 0.43 & 0.48 & 0.46 & 0.73 \\
\hline LEI0160 & 0.30 & 0.47 & 0.36 & 0.39 & 0.50 & 0.52 \\
\hline LEI0169 & 0.33 & 0.53 & 0.36 & 0.37 & 0.36 & 0.59 \\
\hline LEI0079 & 0.55 & 0.44 & 0.86 & 0.65 & 0.57 & 0.50 \\
\hline LEI0107 & 0.62 & 0.79 & 0.79 & 0.68 & 0.86 & 0.84 \\
\hline$A D L 0183$ & 0.38 & 0.75 & 0.64 & 0.47 & 0.92 & 0.81 \\
\hline$M C W 0145$ & 0.51 & 0.64 & 0.57 & 0.58 & 0.57 & 0.72 \\
\hline \multicolumn{7}{|c|}{ Chromosome 3} \\
\hline LEI0043 & 0.44 & 0.12 & 0.64 & 0.50 & 0.14 & 0.14 \\
\hline$M C W 0169$ & 0.50 & 0.80 & 0.64 & 0.60 & 0.93 & 0.85 \\
\hline$M C W 0083$ & 0.23 & 0.37 & 0.29 & 0.26 & 0.57 & 0.52 \\
\hline$A D L 0370$ & 0.12 & 0.42 & 0.14 & 0.14 & 0.43 & 0.55 \\
\hline$M C W 0222$ & 0.62 & 0.52 & 1.00 & 0.70 & 1.00 & 0.63 \\
\hline LEI0161 & 0.33 & 0.44 & 0.43 & 0.37 & 0.43 & 0.50 \\
\hline LEI0115 & 0.21 & 0.50 & 0.29 & 0.25 & 0.29 & 0.59 \\
\hline$A D L 0371$ & 0.46 & 0.42 & 0.36 & 0.58 & 0.23 & 0.54 \\
\hline LEI0118 & 0.54 & 0.70 & 0.71 & 0.64 & 0.93 & 0.77 \\
\hline$M C W 0277$ & 0.00 & 0.53 & 0.00 & 0.00 & 0.71 & 0.62 \\
\hline$A D L 0127$ & 0.28 & 0.50 & 0.43 & 0.35 & 0.71 & 0.60 \\
\hline$M C W 0116$ & 0.32 & 0.12 & 0.29 & 0.37 & 0.14 & 0.14 \\
\hline \multicolumn{7}{|c|}{ Chromosome 4} \\
\hline LEI0100 & 0.37 & 0.27 & 0.50 & 0.52 & 0.29 & 0.31 \\
\hline ADL0194 & 0.50 & 0.68 & 0.57 & 0.59 & 0.50 & 0.75 \\
\hline LEI0122 & 0.47 & 0.54 & 0.14 & 0.58 & 0.50 & 0.62 \\
\hline LEI0062 & 0.46 & 0.41 & 0.78 & 0.56 & 0.57 & 0.49 \\
\hline LEI0076 & 0.78 & 0.75 & 0.71 & 0.84 & 0.79 & 0.81 \\
\hline$M C W 0240$ & 0.52 & 0.80 & 0.85 & 0.61 & 0.86 & 0.86 \\
\hline LEI0063 & 0.45 & 0.46 & 0.57 & 0.53 & 0.61 & 0.56 \\
\hline LEI0085 & 0.13 & 0.57 & 0.14 & 0.14 & 0.79 & 0.66 \\
\hline$M C W 0174$ & 0.45 & 0.65 & 0.57 & 0.56 & 0.71 & 0.72 \\
\hline
\end{tabular}

*Heterozygosity based on the Hardy-Weinberg expected proportions values, observed and expected heterozygosities and number of alleles per locus for $\mathrm{CC}, \mathrm{TT}, \mathrm{F}_{1} \mathrm{CT}$ and $\mathrm{F}_{1} \mathrm{TC}$ are shown in Figure 5. The range of values for the lines and their $\mathrm{F}_{1}$ generations were: $0.39-0.52$, $0.48-0.71,0.46-0.59$ and $3.12-4.32$ for PIC, observed and expected heterozygosities and number of alleles per locus, respectively. In general, these four genotypic parameters presented similar trends, where the CC line showed the lowest means $(p<0.05)$, except for observed heterozygosity. Therefore, the CC line presented the smallest genotypic diversity in our study. This result may be explained because this line was selected for eight generations on egg traits whereas the TT line was only selected for six generations on performance traits, associated with the different genetic backgrounds from each line. $\mathrm{CC}$ had only one breed in its genetic background, while TT had others three. Fixation of some more alleles in CC than TT might be due to selection cycles during which some alleles in CC were lost. Our results support this hypothesis. Consequently, this line showed the lowest PIC and expected heterozygosity. CC presented a lower average number of alleles per locus than TT. Observed heterozygosity did not differ between CC and TT. Considering the difference in number of alleles, this finding resulted in a higher number of loci not fitting Hardy-Weinberg expected proportions in TT (MCW0058, LEI0169 and LEI0107 in Figure 2, LEI0115 and $A D L 0371$ in Figure 3 and LEI0062 in Figure 4) than in CC (LEI0122, LEI0062, LEI0076 and MCW0174 in Figure 3).

Average observed heterozygosities in $\mathrm{F}_{1} \mathrm{TC}$ (0.71) and CT (0.68) were higher than average expected heterozygosities based on Hardy-Weinberg expected proportions in $\mathrm{F}_{1} \mathrm{TC}(0.57)$ and $\mathrm{CT}(0.57)$ according to Figure 5. Our results were in partial agreement with those from Vanhala et al. (1998) who found that observed heterozygosity ranged from 0.30 up to 0.67 and expected heterozygosity ranged from 0.37 up to 0.67 , respectively, for eight selected chicken lines. However, we expected our heterozygosities might be higher than those authors because our $F_{1}$ generations were obtained from reciprocal crosses between two different founder lines that might have increased these parameters. This difference between both heterozygosities may be explained because the crossbreeding between the two chicken lines, previously submitted to constant and intensive artificial selection programs for different traits and selection emphases, probably lead to fixation of different alleles in each line. In fact, based on our sampling, we found that 31 and 44 alleles were unique in CC and TT lines, respectively. This fact may have maximized the linkage disequilibrium across all loci and probably it will increase the power 
ADL0234
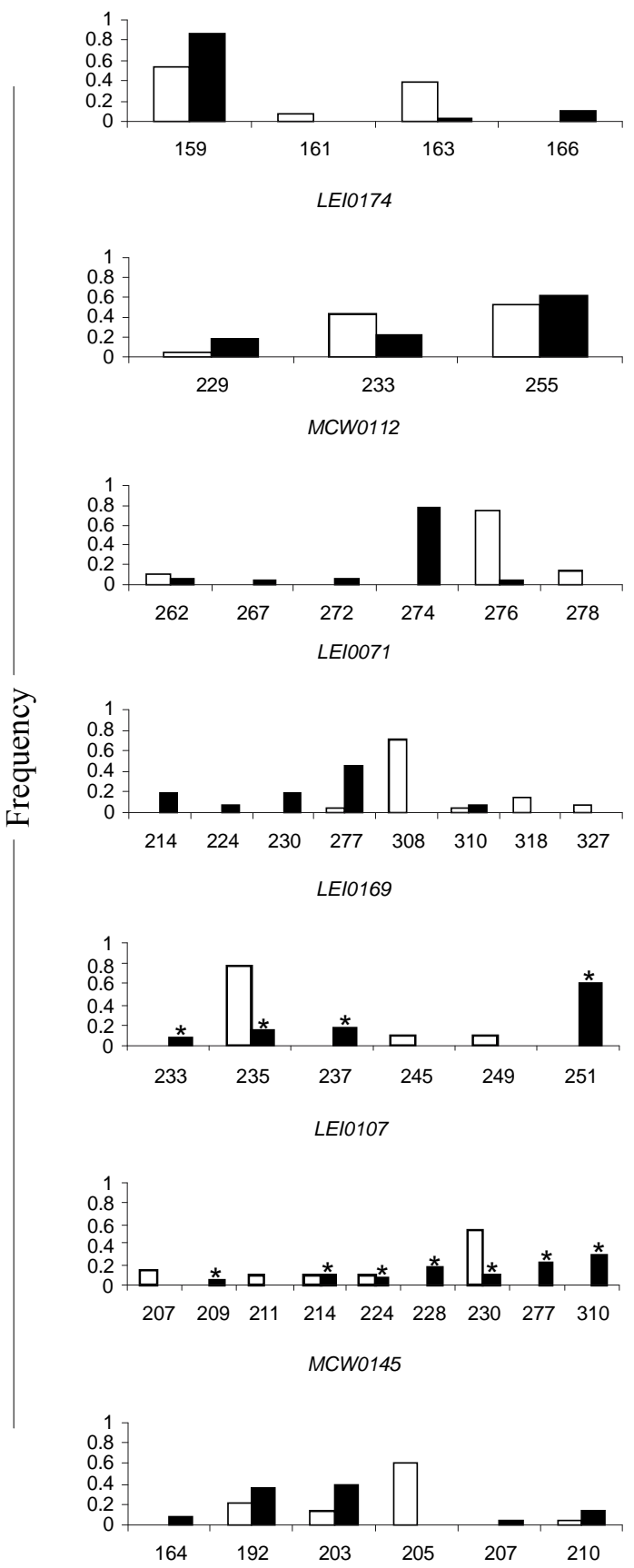

MCW0297
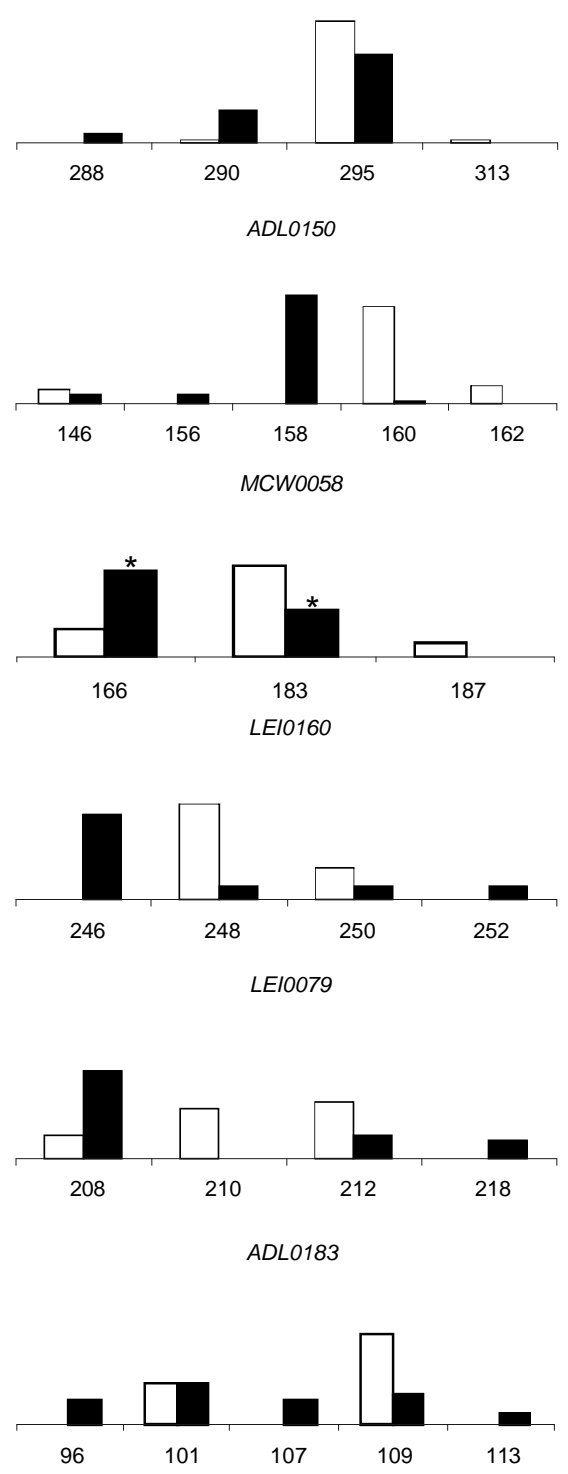

Alleles (bp)

Figure 2 - Summary of overall allele sizes (bp is base pairs) and their respective frequencies across all loci for CC and TT lines and goodness-of-fit test for Hardy-Weinberg expected proportions (HWEP) for chromosome 1. White bars represent the CC line and black bars the TT line. ${ }^{*} p<0.05$ according to Markov chain method test for HWEP.

for QTL detection in our $\mathrm{F}_{2}$ populations. Additionally, the differences between observed and expected heterozygosities in founder lines and their $\mathrm{F}_{1}$ generations may be also due to the genetic drift caused by the sampling error resulting from the small number of males (14) and females (14) selected within each founder line to generate the $\mathrm{F}_{1}$ s. Therefore, the genetic diversity in parental lines and their reciprocal $\mathrm{F}_{1} \mathrm{~s}$ might actually be higher than the one calculated here.

Although comparison of results from different studies of this nature can be difficult because each one uses specific populations generated from different lines assessed by different markers, we tried to compare 

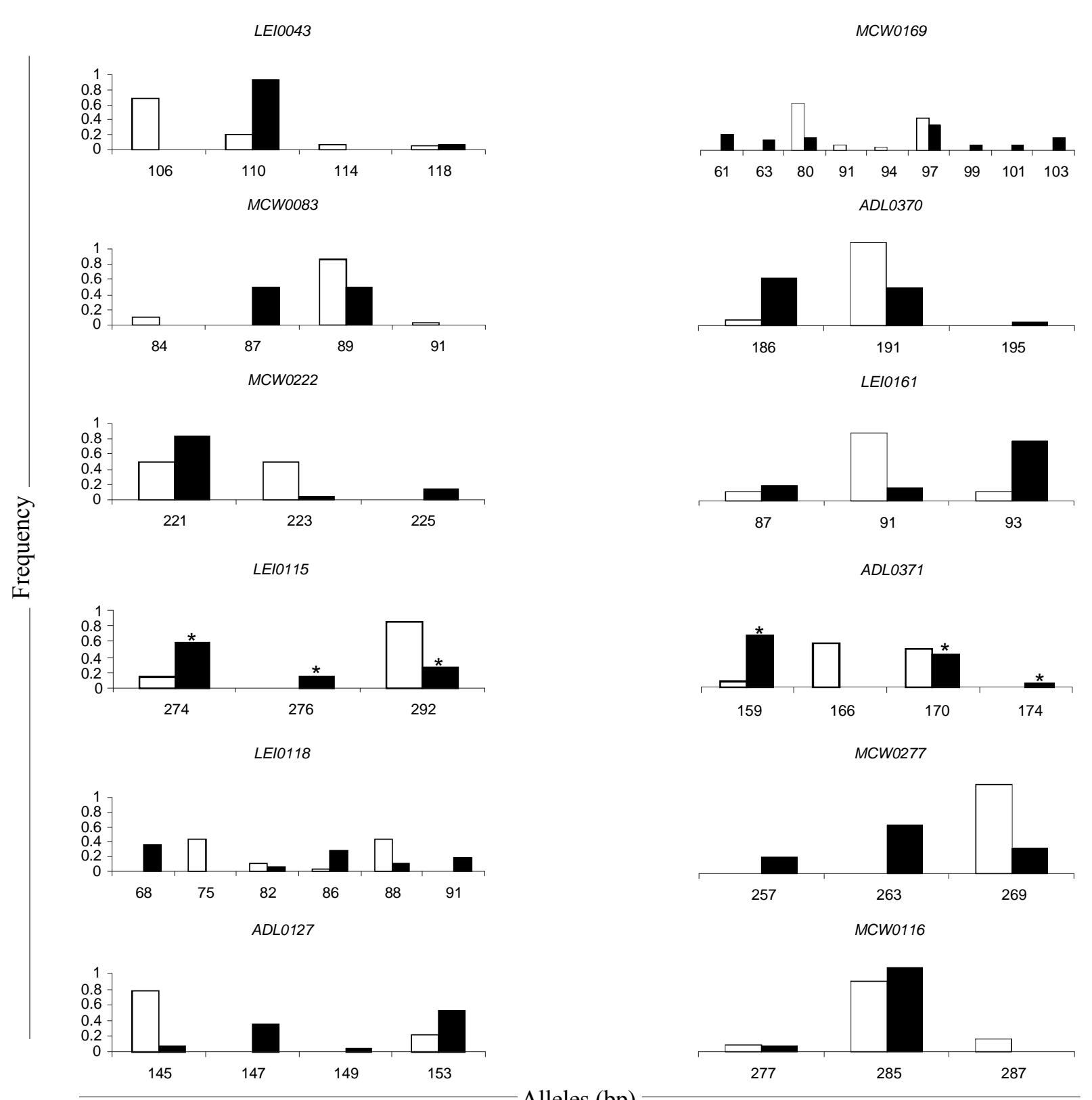

Alleles (bp)
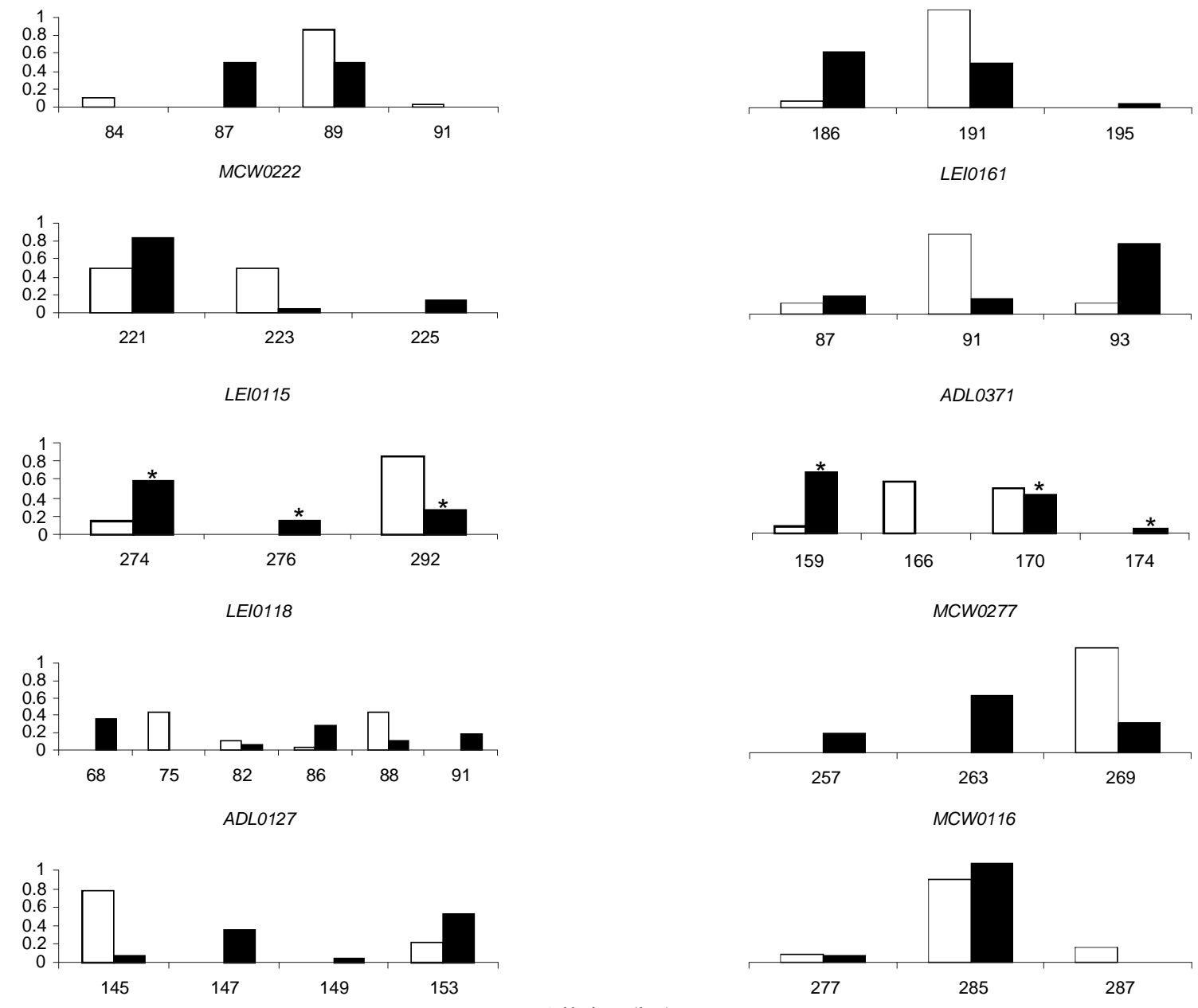

Figure 3 - Summary of overall allele sizes (bp is base pairs) and their respective frequencies across all loci for CC and TT lines and goodness-of-fit test for Hardy-Weinberg expected proportions (HWEP) for chromosome 3. White bars represent the CC line and black bars the TT line. ${ }^{*} p<0.05$ according to Markov chain method test for HWEP.

our results with those that had already been published. Our results (Figure 5) were similar to those of Crooijmans et al. (1996) who reported average PIC $(0.45)$, average estimated heterozygosity $(0.52)$ and average number of alleles per locus (3.6) in broiler dam and male lines. Vanhala et al. (1998) found average number of alleles of 5.7 per locus in a commercial broiler line while Kaiser et al. (2000) determined the average number of alleles to be 2.85 per locus in two broiler chicken populations from two different primary breeding companies.
Associating high observed heterozygosity and PIC values in both $\mathrm{F}_{1}$ generations (Figure 5) is very interesting because they may open the possibility to increase the power for QTL detection through selection of informative markers (Lynch $\&$ Walsh, 1998) and informative $F_{1}$ families (Zhu et al., 2001), reducing genotyping costs in QTL studies. Furthermore, our results will be useful to compare the informativeness of microsatellite markers with other studies and help other groups interested in mapping QTL in chickens to select 


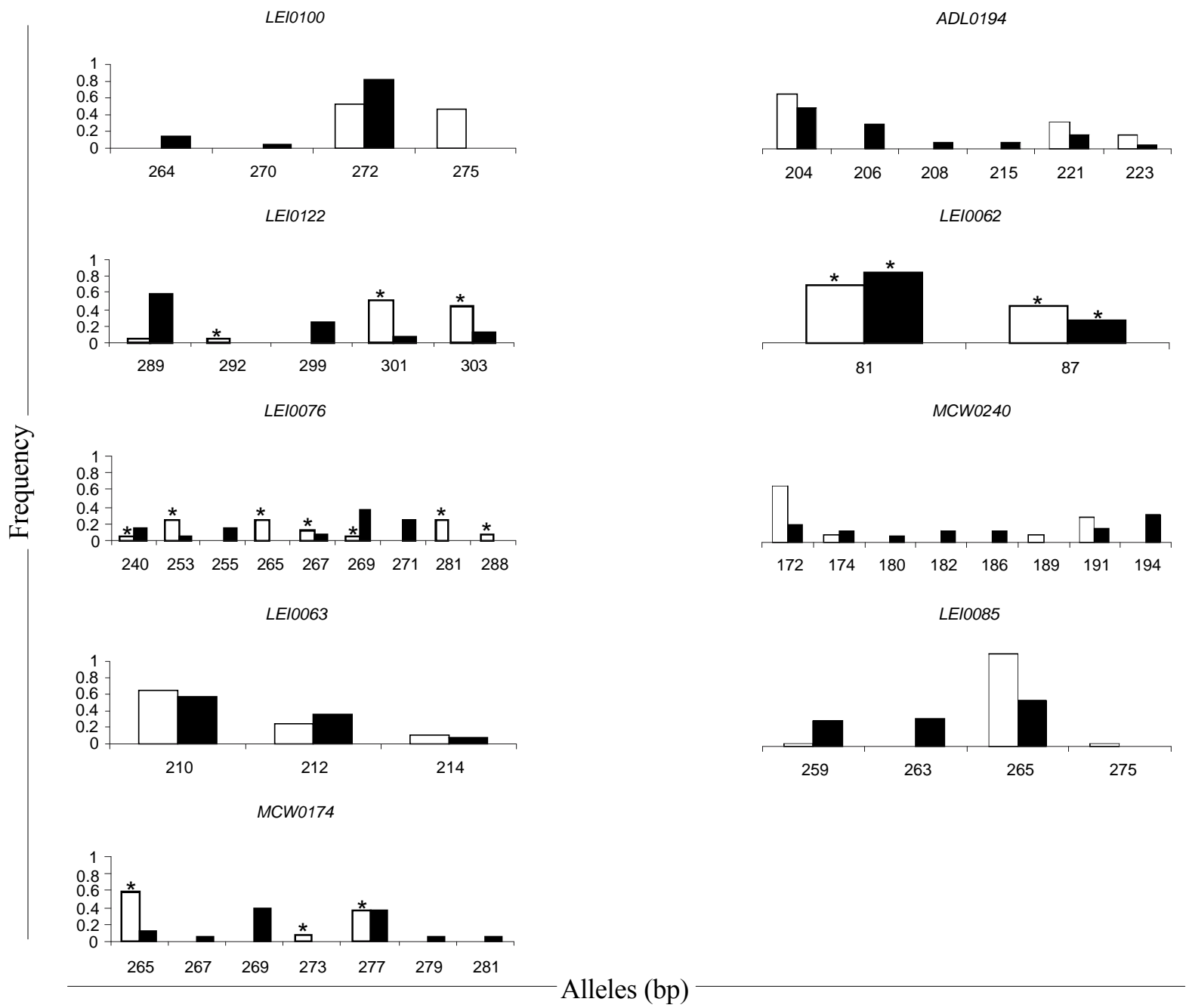

Figure 4 - Summary of overall allele sizes (bp is base pairs) and their respective frequencies across all loci for CC and TT lines and goodness-of-fit test for Hardy-Weinberg expected proportions (HWEP) for chromosome 4. White bars represent the CC line and black bars the TT lines. ${ }^{*} p<0.05$ according to Markov chain method test for HWEP.

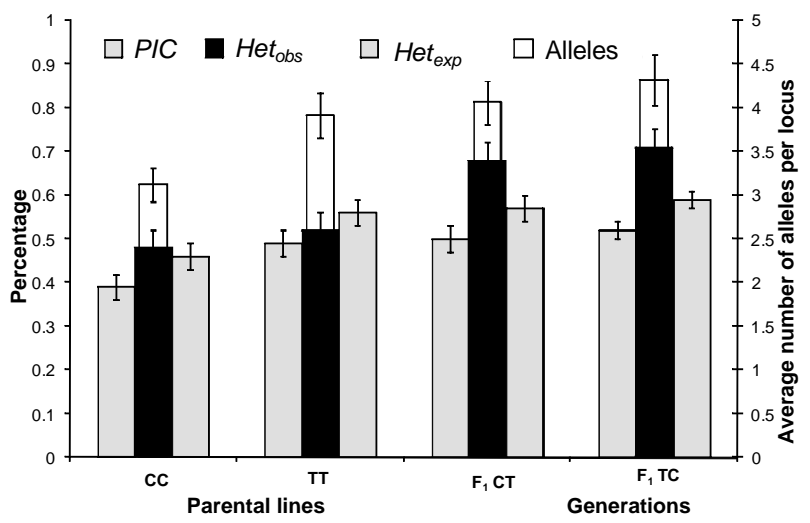

Figure 5 - Means \pm standard errors of the polymorphism information content (PIC), observed heterozygosity $\left(H_{e t} t_{o b s}\right)$, expected heterozygosity $\left(\mathrm{Het}_{\text {exp }}\right)$, in percentages (left scale), and number of alleles per locus (right scale) for $\mathrm{CC}$ and $\mathrm{TT}$ lines and their reciprocal $\mathrm{F}_{1}$ generations $\left(\mathrm{F}_{1} \mathrm{CT}\right.$ and $\left.\mathrm{F}_{1} \mathrm{TC}\right)$ across all loci. markers based on the informativeness of markers used in our study.

\section{ACKNOWLEDGEMENTS}

To FAPESP and EMBRAPA/PRODETAB for financial support. M.F. Rosário received scholarship from FAPESP (process number 04/02080-2). A.A.F. Garcia and L.L. Coutinho are recipients of research productivity scholarship from CNPq.

\section{REFERENCES}

ABASHT, B.; DEKKERS, J.C.M.; LAMONT, S.J. Review of quantitative trait loci identified in the chicken. Poultry Science, v.85, p.2079-2096, 2006.

AL-NASSER, A.; AL-KHALAIFA, H.; AL-SAFFAR, A.; KHALIL, F.; ALBAHOUH, M.; RAGHEB, G.; AL-HADDAD, A.; MASHALY, M. Overview of chicken taxonomy and domestication. World's Poultry Science Journal, v.63, p.285-300, 2007. 
AMBO, M.; CAMPOS, R.L.R.; MOURA, A.S.A.M.T.; BOSCHIERO, C.; ROSÁRIO, M.F.; LEDUR, M.C.; NONES, K.; COUTINHO, L.L. Genetic linkage maps of chicken chromosomes $6,7,8,11$ and 13 from a Brazilian resource population. Scientia Agricola, v. 65, p.447-452, 2008.

BOTSTEIN, D.; WHITE, R.L.; SKOLNICK, M.; DAVIS, R.W. Construction of a genetic-linkage map in man using restriction fragment length polymorphisms. American Journal of Human Genetics, v.32, p.314-331, 1980.

CROOIJMANS, R.P.M.A.; GROEN, A.F.; KAMPEN, A.J.A. van; BEEK, S. van der; POEL, J.J. van der; GROENEN, M.A.M. Microsatellite polymorphism in commercial broiler and layer lines using pooled blood samples. Poultry Science, v.75, p.904909, 1996

FIGUEIREDO, E.A.P.; ROSA, P.S.; SCHEUERMANN, G.N.; JAENISCH, F.R.F.; SCHMIDT, G.S.; LEDUR, M.; BRENTANO, L.; COSTA, C.A.F. Genetic gain in body weight feed conversion and carcass traits in White Plymouth Rock broiler strain Embrapa 021. In: WORLD CONFERENCE ON ANIMAL PRODUCTION, 9.; REUNIÃO DA ASSOCIACÃO LATINOAMERICANA DE PRODUÇÃO ANIMAL, 18., Porto Alegre, 2003. Proceedings. Porto Alegre: WAAP/ALPA, 2003a. CD-ROM.

FIGUEIREDO, E.A.P.; SCHMIDT, G.S.; LEDUR, M.C.; AVILA, V.S.; BRUM, P.A.R.; FIORENTIN, L.; JAENISCH, F.R.F. Genetic gain in egg production and egg weight in White Leghorn Embrapa 011. In: WORLD CONFERENCE ON ANIMAL PRODUCTION, 9.; REUNIÃO DA ASSOCIACÃO LATINOAMERICANA DE PRODUÇÃO ANIMAL, 18., Porto Alegre, 2003. Proceedings. Porto Alegre: WAAP/ALPA, 2003b. CD-ROM.

FISHELSON, M.; GEIGER, D. Exact genetic linkage computations for general pedigrees. Bioinformatics, v.18, supplement 1 , p.S189-S198, 2002.

GROENEN, M.A.M.; CHENG, H.H.; BUMSTEAD, N.; BENKEL, B.F.; BRILES, W.E.; BURKE, T.; BURT, D.W.; CRITTENDEN, L.B.; DODGSON, J.; HILLEL, J.; LAMONT, S.; DE LEON, A.P.; SOLLER, M.; TAKAHASHI, H.; VIGNAL, A. A consensus linkage map of the chicken genome. Genome Research, v.10, p.137-147, 2000.

GUO, S.W.; THOMPSON, E.A. Performing the exact test of HardyWeinberg proportion for multiple alleles. Biometrics, v.48, p.361-372, 1992 .

HILLEL, J. Map-based quantitative trait locus identification. Poultry Science, v.76, p.1115-1120, 1997.

HILLEL, J.; GROENEN, M.A.M.; TIXIER-BOICHARD, M.; KOROL, A.B.; DAVID, L.; KIRZHNER, V.M.; BURKE, T.; BARRE-DIRIE，A.; CROOIJMANS，R.P.M.A.; ELO，K.; FELDMAN, M.W.; FREIDLIN, P.J.; MÄKI-TANILA, A.; OORTWIJN, M.; THOMSON, P.; VIGNAL, A.; WIMMERS, K.; WEIGEND, S. Biodiversity of 52 chicken populations assessed by microsatellite typing of DNA pools. Genetics Selection Evolution, v.35, p.533-557, 2003.

KAISER, M.G.; YONASH, N.; CAHANER, A.; LAMONT, S.J. Microsatellite polymorphism between and within broiler populations. Poultry Science, v.79, p.626-628, 2000.

KALINOWSKI, S.T.; TAPER, M.L.; MARSHALL, T.C. Revising how the computer program CERVUS accommodates genotyping error increases success in paternity assignment. Molecular Ecology, v.16, p.1099-1106, 2007.

LEDUR, M.C.; BERTANI, G.R. Análise genômica na avicultura: resultados e perspectivas. In: SIMPÓSIO NACIONAL DE MELHORAMENTO ANIMAL, 4., Campo Grande, 2002. Resumos. Campo Grande: SBMA, 2002. CD-ROM.

LYNCH, M.; WALSH, B. Genetics and analysis of quantitative traits. Sunderland: Sinauer Associates, 1998. 980p.

MARSHALL, T.C.; SLATE, J.; KRUUK, L.E.B.; PEMBERTON, J.M. Statistical confidence for likelihood-based paternity inference in natural populations. Molecular Ecology, v.7, p.639-655, 1998.
NEI, M. Molecular evolutionary genetics. New York: Columbia University Press, 1987. 512p.

NONES, K.; LEDUR, M.C.; RUY, D.C.; BARON, E.E.; MELO, C.M.R.; MOURA, A.S.A.M.T.; ZANELLA, E.L.; BURT, D.W.; COUTINHO, L.L. Mapping QTLs on chicken chromosome 1 for performance and carcass traits in a broiler $\mathrm{x}$ layer cross. Animal Genetics, v.37, p.95-100, 2006.

NONES, K.; LEDUR, M.C.; RUY, D.C.; BARON, E.E.; MOURA, A.S.A.M.T.; COUTINHO, L.L. Genetic linkage map of chicken chromosome 1 from a Brazilian resource population. Scientia Agricola, v.62, p.12-17, 2005.

RAYMOND, M.; ROUSSET, F. GENEPOP (version 1.2): population genetics software for exact tests and ecumenicism. Journal of Heredity, v.86, p.248-249, 1995.

ROMANOV, M.N.; WEIGEND, S. Analysis of genetic relationships between various populations of domestic and jungle fowl using microsatellite markers. Poultry Science, v.80, p.1057-1063, 2001.

ROSÁRIO, M.F.; LEDUR, M.C.; MOURA, A.S.A.M.T.; BARON, E.E.; NONES, K.; CAMPOS, R.L.R.; AMBO, M.; RUY, D.C.; COUTINHO, L.L.; GARCIA, A.A.F. Genetic diversity parameters in two experimental chicken populations designed for mapping quantitative trait loci. In: WORLD CONGRESS ON GENETICS APPLIED TO LIVESTOCK PRODUCTION, 8., Belo Horizonte, 2006. Proceedings. Belo Horizonte: WGALP/SBMA, 2006. CD-ROM.

RUY, D.C.; NONES, K.; BARON, E.E.; LEDUR, M.C.; MELO, C.M.R.; AMBO, M.; CAMPOS, R.L.R.; COUTINHO, L.L. Strategic marker selection to detect quantitative trait loci in chicken. Scientia Agricola, v.62, p.111-116, 2005.

SCHMID, M.; NANDA, I.; HOEHN, H.; SCHARTL, M.; HAAF, T.; BUERSTEDDE, J.M.; ARAKAWA, H.; CALDWELL, R.B.; WEIGEND, S.; BURT, D.W.; SMITH, J.; GRIFFIN, D.K.; MASABANDA, J.S.; GROENEN, M.A.M.; CROOIJMANS, R.P.M.A.; VIGNAL, A.; FILLON, V.; MORISSON, M.; PITEL, F.; VIGNOLES, M.; GARRIGUES, A.; GELLIN, J.; RODIONOV, A.V.; GALKINA, S.A.; LUKINA, N.A.; BEN-ARI, G.; BLUM, S.; HILLEL, J.; TWITO, T.; LAVI, U.; DAVID, L.; FELDMAN, M.W.; DELANY, M.E.; CONLEY, C.A.; FOWLER, V.M.; HEDGES, S.B.; GODBOUT, R.; KATYAL, S.; SMITH, C.; HUDSON, Q.; SINCLAIR, A.; MIZUNO, S. Second report on chicken genes and chromosomes 2005. Cytogenetic and Genome Research, v.109, p.415-479, 2005.

SLATE, J.; MARSHALL, T.C.; PEMBERTON, J.M. A retrospective assessment of the accuracy of the paternity inference program CERVUS. Molecular Ecology, v.9, p.801-808, 2000.

VANHALA, T.; TUISKULA-HAAVISTO, M.; ELO, K.; VILKKI, J.; MÄKI-TANILA, A. Evaluation of genetic variability and genetic distances between eight chicken lines using microsatellite markers. Poultry Science, v.77, p.783-790, 1998.

ZANELLA, E.L.; LEDUR, M.C.; SCHMIDT, G.S.; JAENISCH, F.R.F.; COUTINHO, L.L. Development of a new reference population for QTL detection in poultry. In: ANNUAL MEETING OF THE POULTRY SCIENCE ASSOCIATION, 89., Montreal, 2000. Abstracts. Savoy: PSA, 2000. p.61.

ZHU, J.J.; LILLEHOJ, H.S.; CHENG, H.H.; POLLOCK, D.; SADJADI, M.; EMARA, M.G. Screening for highly heterozygous chickens in outbred commercial broiler lines to increase detection power for mapping quantitative trait loci. Poultry Science, v. 80 , p.6-12, 2001 .

Received March 18, 2008

Accepted August 26, 2008 